\title{
ADVANCES IN SOIL SALINITY DETECTION IN ARID AND SEMI- ARID REGIONS USING SALINITY AND VEGETATION INDICES
}

\author{
A. S. El-Hassanin (1), S. A. Abdallah (2), N. M. Saleh ${ }^{(1)}$ and M. S. Abou Kota(2) \\ (1) Institute of African Research And Studies- Cairo University, Egypt. \\ (2) Soils, Water And Environment Research Institute- Agriculture Research Center, Egypt. \\ aboukota.m@gmail.com mohamed_elsayed1185@yahoo.com
}

Received: Jun. 4, 2016

Accepted: Jun. 22, 2016

\begin{abstract}
Soil salinization as a result of natural or of human-induces processes is a serious global-scale problem. Salinization is a major reason for soil resources degradation and declining of soil fertility. From an ecological and economic point of view it is extremely important to follow the occurrence and distribution of soil salinity as well as the intensity of the process. Several studies and efforts in assessing and controlling soil salinity have been made. Remote sensing techniques are widely used to detect and map the salt-affected areas. The indices used in this research are the normalized differential vegetation index (NDVI), normalized difference salinity index (NDSI) and modified soil adjust vegetation Index (MSAVI). MSAVI was found to be effective in discriminating the plants under severe and moderate conditions of soil salinity as well as under non-saline conditions. Temporal trend analysis technique was carried out to detect significant changes in the soil verses vegetation conditions. The obtained results showed that the studied area is mostly covered by field crops where, NDVI values were ranging between 0 and 0.82 and MSAVI ranging from 0.02 to 0.70 . The NDSI values, however, showed the land salinity classes, as they were fluctuated from 0.01 to 0.89 .
\end{abstract}

Key words: NDSI, NDVI, MSAVI, LAND SAT 8 image.

\section{INTRODUCTION.}

Salinization is a major reason for degradation of the soil resources and declining of soil fertility. From an ecological and economic point of view it is extremely important to establish the occurrence and distribution of soil salinization as well as the intensity of the process. The magnitude and extent of soil salinity are affected climate change, soil parent material, inadequate irrigation and drainage systems and intensification of agricultural land use. To counteract deterioration of agricultural lands, the methods of managing and monitoring of soil resources must be improved. Today the world faces unprecedented set of environmental problems many of which are related to ecosystem depletion and destruction.

At present, conservation of natural resources is a fundamental and crucial ecological issue all over the planet. Soil cover is an essential component of the natural environment. It resembles the relationships between the other environmental components (rocks, water, climate, vegetation, human activities) and is an indicator of the ecological status of the landscape. Soil salinization is nowadays a world-wide problem relevant to the global concern of natural resources preservation. Based on the statistics concluded in 2008, more than 77 million hectares $(5 \%$ of cultivated lands) in the world are affected by excess salt. Increased salinization of arable land will cause $50 \%$ land loss by the middle of $21^{\text {st }}$ salt-spoiled soils constitute more than half of all irrigated lands. Every day for more than 20 years, an average of 2000 hectares of irrigated land in arid and semi-arid areas across 75 countries have been degraded by salt century (Sheng et al., 2008; Rumiana et 
al., 2015).Soil salinity is one of the most common soil-degradation processes, particularly prevalent in both arid and semiarid areas (Ceuppens et al., 1997).

Salinity is a natural characteristic of the soil but salinization is caused by some anthropogenic activities. Salinity is defined as the salt accumulation in the soil (Katawatin and Kotrapat, 2005; Metternicht and Zinck, 2008). Soil salinization occurs when the weathered soil minerals and salts from irrigation water are not washed away by rain or by irrigation and instead they form excess amounts of $\mathrm{Na}^{+}, \mathrm{K}^{+}, \mathrm{Ca}^{2+}, \mathrm{Mg}^{2+}$ and $\mathrm{Cl}^{-}$ions (Fernandez-Buces et al., 2006). Under natural conditions, this phenomenon characterizes areas of low or decreasing precipitation, where there is poor drainage and rising water table level. Globally, salinization of agricultural soils is estimated at $45 \mathrm{Mha}$, and is growing at between 200000 and 500000 ha./ year (UNEP, 2007; Narmada et al., 2015).

Remote sensing has been advocated as a powerful tool to play an important role in identifying, mapping, and monitoring soil salinity and salinization. The integration of remote sensing technologies in salinity studies is an expanding field of research and publication, taking advantage of steadily improving technology for remote and proximal sensing of land features at the terrain surface as well as in subsurface layers. Over the last two decades, several review papers have described the usefulness of remote sensing for salinity mapping and hazard assessment (Mougenot et al., 1993; Metternicht and Zinck, 2003; Farifteh et al., 2006). Now it might be the appropriate time to offer a comprehensive volume on the subject along with a large spectrum of recent and ongoing research using technological developments in sensors and platforms and new methodological approaches. The approach to the problem of delineating saline soils using remote sensing data and GIS techniques has been proved in many recent studies to be most efficient (Sadia and Nikos, 2005). The review is devoted to studying approaches used on the remotely sensed data to delineate the salt affected areas worldwide.

Implementation of remote sensing data in soil salinity mapping is firm to employ since salinization is not a static process. Therefore, a number of derivatives and alternatives to normalized difference vegetation index have been anticipated to discourse soils salinization monitoring and mapping (Montandon and Small, 2008; Yang et al., 2011). Different remote sensing indices such as the salinity index (SI), the normalized difference salinity index (NDSI), and the brightness index (BI) in addition to normalized difference vegetation index (NDVI) were implemented to investigate the means by which these indices work for soil salinity mapping in the arid environment (Douaoui et al., 2006 and Jiapaer et al., 2011). The salinity index (SI), which combines the blue and red bands, is sensitive to the surface reflectance of saltaffected land with sparse vegetation cover (Douaoui et al., 2006). The perspective of using remote sensing data and GIS practices has been demonstrated in several scholarly works to be the most resourceful (Roa et al., 1991; Elhag and Bahrawi, 2014). The comprehensive use of satellite remote sensing and GIS has been recognized to be a cost-effective method for monitoring soils salinization poorly drained basins (Goossens et al., 1993 and Casas, 1995). However, state of the art outcome specifies that there is no ideal combination of datatype and questioning method which can be functional with identical realization across approximately several environmental conditions (Wardlow and Egbert, 2008; Douaoui et al., 2006). The aim of current research project is to differentiate the 
salinized soils from non-salinized soils implementing different approaches of digital image classification and band math techniques. To reach this objective, several soil salinity indices were applied to the Landsat 8 data.

\section{Description of study area:}

\section{Location:}

El Beheira Governorate occupies the main part of the western region of the Nile Delta. It lies on the western side of Rossetta Branch and is bounded to the north by ldku and Maryut lakes, It lies between longitudes $30^{\circ} 40^{\prime}$ and $29^{\circ} 50^{\prime} \mathrm{E}$ and latitudes $31^{\circ} 30^{\prime}$ and $30^{\circ} 40^{\prime} \mathrm{N}$, (Map 1).

\section{Climate}

The climatic condition of the study area are typically arid to semi-arid. It characterized by a long hot dry summer, mild winter with little rainfall, high evaporation with moderately to high relative humidity. With such high annual evapotranspiration condition both irrigation water and energy costs required for irrigation would be very high. The meteorological data and climate diagram of the study area are presented in Table (1) and Figure (1).

\section{Geomorphology}

The Nile Delta region covers an area of about 39000 square $\mathrm{km}$. It extends $250 \mathrm{~km}$ from Lake Manzala on the east to El-Max, Alexandria on the west and $175 \mathrm{~km}$ in distance from Cairo in the south to Lake Burullus (North). The ancient Nile activity would be responsible for the macro- relief and the general slope from south to north towards the sea while the recent Nile activity would lead to the formation of the microrelief. Surface level of the soil at the main branches or the secondary canals has been higher than valley between them. Within the studied area different geomorphological features have been distinguished (FAO, 1964; El Nahal et al., 1977; Shata et al., 1978). According to these authors three geomorphic units can be distinguished namely; Alluvial Plain (Recent Nile alluvium); Fluvial- marine Plain and Desert Plain.

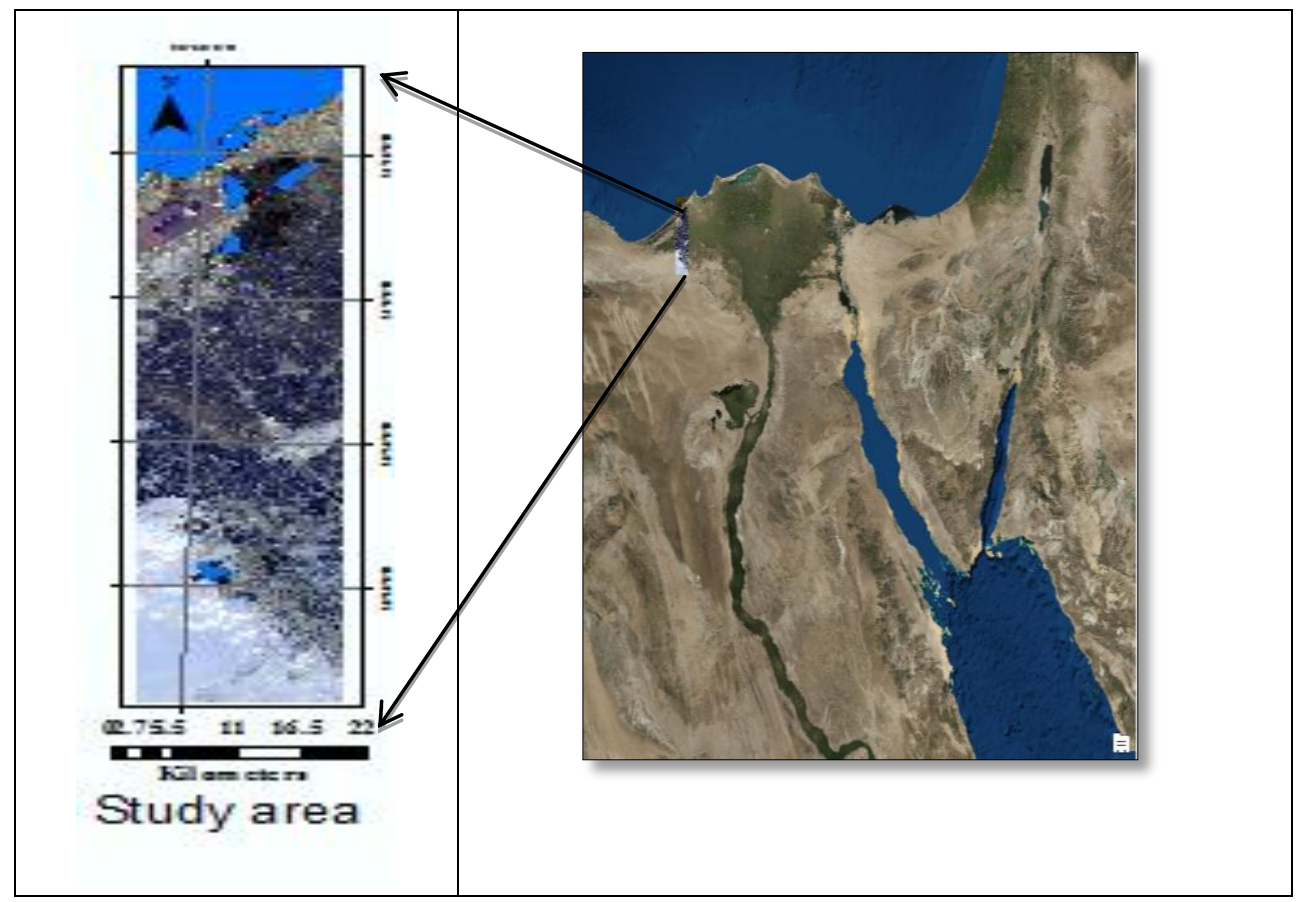

Map (1): Location map of the study area. 
El-Hassanin, et al.

Table (1): Climatological data of the studied area (2009-2014), (of Alexandria meteorological station).

\begin{tabular}{|c|c|c|c|c|c|c|c|}
\hline \multirow{2}{*}{ Month } & \multicolumn{2}{|c|}{$\begin{array}{c}\text { Temperature } \\
\left({ }^{\circ} \mathrm{C}\right)\end{array}$} & $\begin{array}{c}\text { Relative } \\
\text { Humidity }(\%)\end{array}$ & $\begin{array}{c}\text { Wind speed } \\
2 \mathrm{~m} \\
(\mathrm{~m} / \mathrm{sec})\end{array}$ & $\begin{array}{c}\text { Rainfall } \\
(\mathrm{mm})\end{array}$ & $\begin{array}{c}\text { Sun shine } \\
\text { duration }(\mathrm{hr})\end{array}$ & $\begin{array}{c}\mathrm{ET}_{0} \\
(\mathrm{~mm} / \mathrm{day})\end{array}$ \\
\cline { 2 - 7 } Jan. & 23.40 & 10.00 & 68.00 & 2.40 & 17.70 & 11.10 & 20.10 \\
\hline Feb. & 22.00 & 10.19 & 65.00 & 2.70 & 6.50 & 11.00 & 22.30 \\
\hline Mar. & 24.11 & 14.00 & 64.00 & 3.20 & 0.00 & 11.80 & 45.60 \\
\hline Apr. & 25.00 & 13.91 & 62.00 & 2.80 & 0.00 & 12.80 & 74.30 \\
\hline May & 29.90 & 17.50 & 66.00 & 2.90 & 0.00 & 13.60 & 95.70 \\
\hline Jun. & 32.00 & 22.10 & 68.00 & 2.90 & 0.00 & 14.00 & 112.20 \\
\hline Jul. & 34.00 & 24.00 & 67.00 & 2.90 & 0.00 & 14.00 & 120.60 \\
\hline Aug. & 34.50 & 26.00 & 72.00 & 3.10 & 0.00 & 13.20 & 128.00 \\
\hline Sep. & 34.50 & 25.50 & 65.00 & 2.70 & 0.00 & 12.20 & 117.40 \\
\hline Oct. & 31.61 & 23.00 & 64.00 & 2.50 & 6.00 & 11.30 & 99.10 \\
\hline Nov. & 27.50 & 15.80 & 72.00 & 1.80 & 1.00 & 10.40 & 65.00 \\
\hline Dec. & 21.90 & 11.80 & 69.00 & 2.40 & 26.30 & 10.00 & 24.50 \\
\hline
\end{tabular}

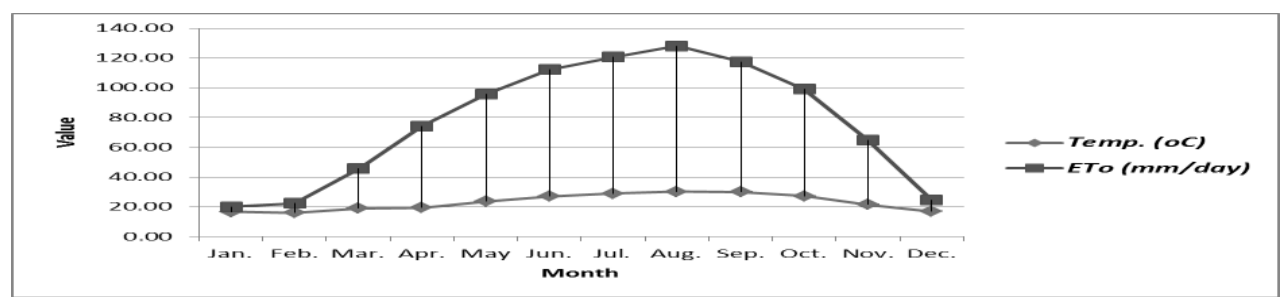

Figure (1): Climate diagram of the studied area.

\section{Hydrological conditions}

Groundwater (mostly recharged by the Nile water) is of relatively limited use in the Valley but is specially used in the desert fringes. Regional data on the hydrological conditions of the northwestern coastal zone of Egypt can be found in several publications such as (Guindy, 1989; Awad et al., 1994; Shaaban, 2001). The studied area is characterized by extremely low rainfall with high evaporation and evapotranspiration rates. The scanty rainfall is confined to the winter season and rain usually occurs as thunderstorms and showers. Fresh groundwater in the region is believed to originate mainly from Nile delta to east of the investigated area; seepage of the fresh water from the Nile delta may also reach to the west of the studied area, similar results (Sharaky et al., 2007).

\section{MATERIALS AND METHODS}

The remotely sensed data of Landsat 8 image path 177 and raw 38 acquired on 2015-01-20 were the main source of information. Arc GIS 10.3 and ENVI 5.1 software's used to identify the boundaried and land features of the studied are based 
on the bands values to the top of Atmosphere (TOA) radians at the satellite image. This is applied after band wise conversion of the quantized and calibrated scaled Digital Numbers (DN). These software's are used to define and differentiate the saline from the non-saline soils of the studies area. Different indices namely; NDVI, NDSI and MSAVI were applied to the image of the study area (Huete, 1988). NDVI was calculated to differentiate between the areas of high from those of low vegetation cover. MSAVI was also calculated to identify the extent of healthy vegetation cover in the area. Additionally, in order to enhance the differentiation of saline areas, suppressing the vegetation, other index namely Normalized Difference Salinity Index (NDSI) have been employed depending on the spectral response of salt-affected soils (Odeh et al.,1995).

\section{RESULTS AND DISCUSSION Remote sensing applied to salinity and vegetation delineation:}

\section{Normalized difference salinity index (NDSI):}

The use of NDSI index gives the differential preferences to achieve adequate soil salinity estimation on a large scale using remote sensing data. The dynamicity of the soil salinization process added further complications to designating salt-affected soils in a systematic uniform perspective. The use of different algorithms based on implementing different combinations and/or ratios of OLI-8 bands in the form of soil salinity index evidenced to be more efficient to overcome soil dynamicity problems (Lei et al., 2014; Zhang et al., 2015).The selection of the sensitive bands adequate for proper soil salinity mapping is not systematically generalized (Zhang et al., 2013; Zhang et al., 2015). Land salinity classes of the studied area are shown in Figure (2). The evaluation of different soil salinity indices was based on the regression model fit, effect significance, and model parameters. The NDSI is computed following the equation (Major et al., 1990):

$$
\mathrm{NDSI}=\frac{\mathrm{R}-\mathrm{NIR}}{\mathrm{R}+\mathrm{NIR}}
$$

Which: NIR and $R$ are infrared red and red bands, respectively.

For this application, the NDSI dataset contained four training areas representing highly saline (mean value of $0.44-0.89$ ), saline (mean value of $0.13-0.43$ ), moderately saline (mean value of 0.08 0.12 ) and slightly saline (mean value of $(0.01-0.07)$ areas were chosen, figure 2 and the supervised classification method was applied and the classification result is given in figure 2. As can be seen, the pale pink areas represent the slightly saline to low saline areas, orange areas represent the moderately saline areas, yellow areas represent saline areas and the brown areas represent the very high saline areas.

\section{Normalized difference vegetation index (NDVI):}

The NDVI was used to assess, monitor, and compare landscapes and it can be used to understand the various characteristics of vegetation community Elhag, (2016). Wesis et al., (2004) concluded that NDVI is an appropriate tool for describing the vegetation variability in arid and semi-arid regions. It allows long time-scale investigations of Near-infrared energy which is highly reflected by the cell wall/air interface that is part of the internal structure of plants. The first vegetative indices were simple ratios of these spectral bands, mainly using the red band and the near-infrared (NIR) band. The NDVI is a normalized difference measure comparing the near infrared (NIR) and visible red bands using the formula (Rouse et al., 1973):

$$
\mathrm{NDVI}=\frac{\mathrm{NIR}-\mathrm{RED}}{\mathrm{NIR}+\mathrm{RED}}
$$




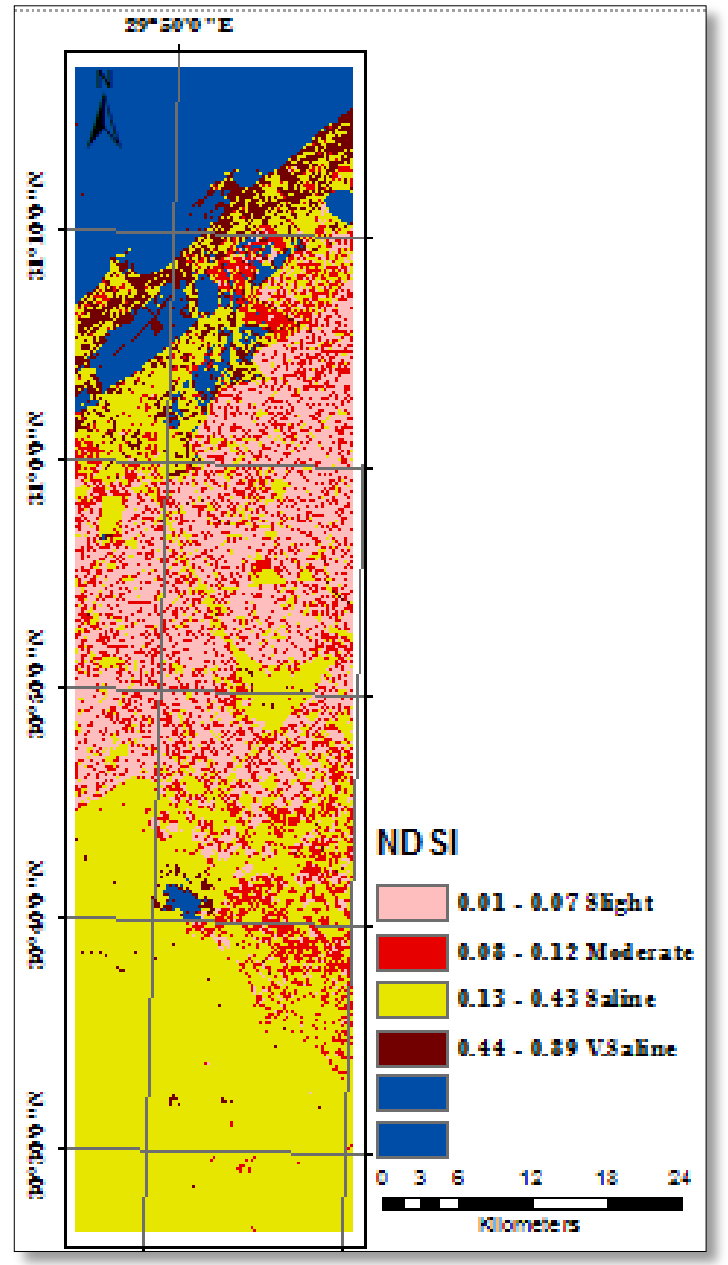

Figure (2): Classified LANDSAT 8 image using NDSI equation.

Training areas representing highly vegetated (mean value of $0.60-0.82$ ), moderately vegetated (mean value of 0.4 0.59 ), and slightly vegetated (mean value of $0.21-0.39$ ) and non- vegetated (mean value was smaller than 0.20 ) areas were chosen and the supervised classification method was applied. The classification result is given in Figure $3 \mathrm{a}$ where, the dark green areas represent the highly vegetated areas, yellow areas represent the non-vegetated areas and the pale green areas represent the low-vegetated areas. Accordingly, it could be concluded that the area is mainly highly vegetated area.

\section{Modified soil adjust vegetation index (MSAVI):}

The SAVI was developed to minimize soil influences on canopy spectra by incorporating a soil adjustment factor (L) into the denominator of NDVI equation. For optimal adjustment of the soil effect, however, the $(L)$ factor should vary inversely with the amount of vegetation present. (L) is a soil fudge factor that varies from 0 to 1 depending on the soil, often set to 1. SAVI 
was also calculated to understand the extent of healthy vegetation cover in the area.The modified soil adjusted vegetation index has been shown to increase the dynamic range of the vegetation signal while further minimizing the soil background influences, resulting in greater vegetation sensitivity as defined by a 'vegetation signal' to 'soil noise' ratio. The MSAVI is a type of soil adjust vegetation index SAVI. As the study area is considered an arid and semi-arid area, it is expected that indices which consider soil reflectance can estimate vegetation fraction more accurately than other indices. Results showed that only MSAVI has acceptable outputs (Figure 3b). Qi et al., (1994b) developed the MSAVI2 to more reliably and simply calculate a soil brightness correction factor (Jiang et al., 2007; Qi et al., 1994a; Qi et al., 1994b; Ray, 2011). The MSAVI2 is computed following the equation:

MSAVI2 $=\frac{\left(2 * \text { NIR }+1-\sqrt{(2 * \mathrm{NIR}+1)^{2}-8 *(\mathrm{NIR}-\mathrm{RED})}\right.}{2}$

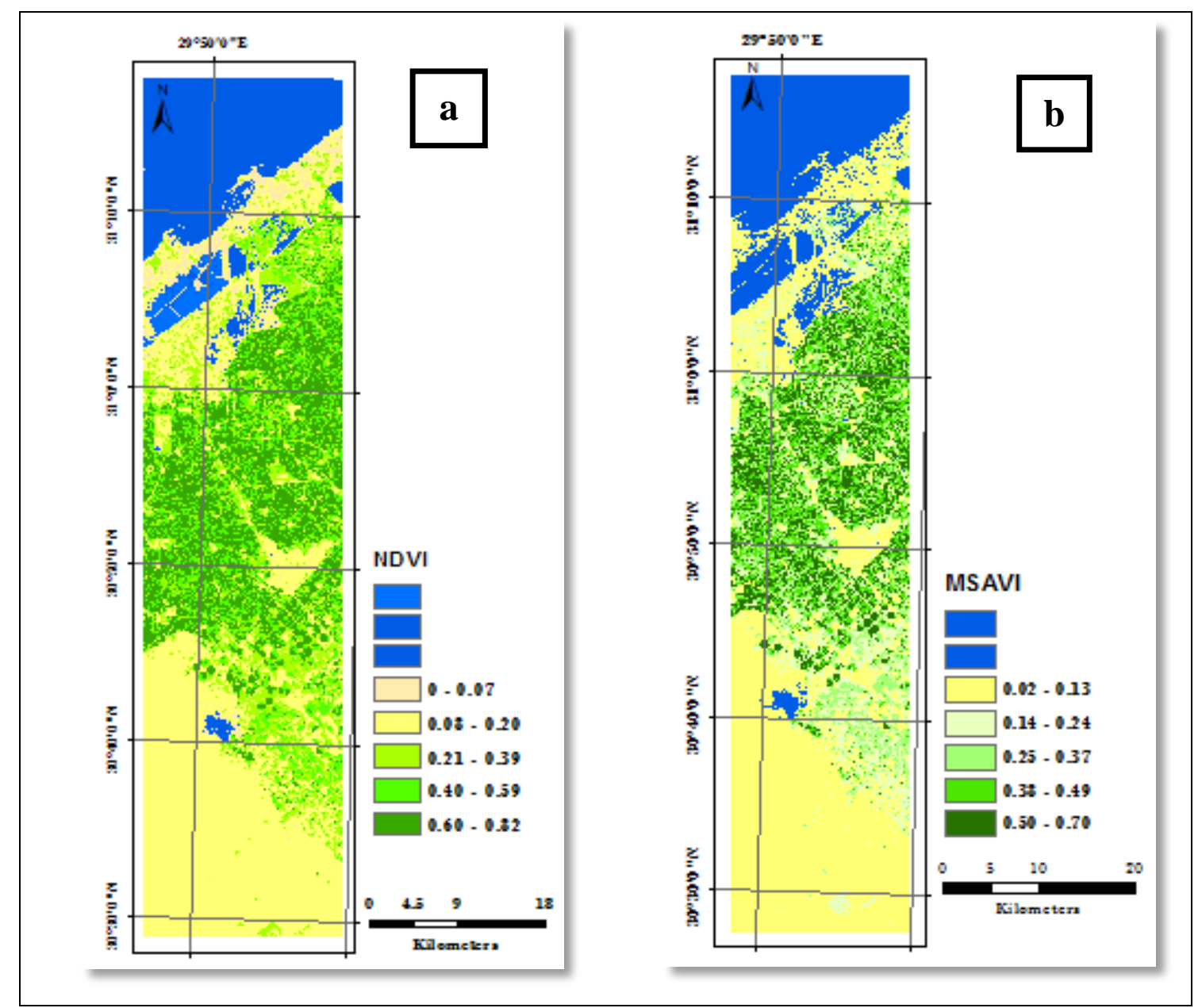

Figure (3): Classified LANDSAT 8 image using NDVI and MSAVI equations. 
MSAVI image in Figure $3 b$ give much importance to the information of internal difference of the vegetation as they expand the extracted spatial information of the vegetation to a certain extent. So they can provide major references for the information extraction of different vegetation type. The chosen training sets were representing highly healthy vegetated type $(0.5-0.7)$, moderately healthy vegetated type $(0.38-$ $0.49)$ and low healthy vegetated type $(0.14-$ 0.37 ). The classification results is given in figure $3 \mathrm{~b}$, where, the dark green color refers to the highly healthy vegetated areas, the olive green color refers to moderate healthy vegetated areas. While, the pale green shows the low to healthy vegetated areas.

\section{CONCLUSIONS}

The results of the current study revealed that the area under investigation is mostly of cultivated land. Monitoring soil salinity of such an area is very crucial as salinity may occur and extent in a way that the soil could lose its productivity. Using remotely sensed data and salinity and vegetation indices has proved to be effective as quick and accurate in monitoring soil salinity. NDSI and MSAVI were employed and showed different salinity classes ranging from non- saline to highly saline. NDVI index differentiates between the highly, low and non- vegetated areas. These results may contribute in managing the soils and take the appropriate measures to control salinity.

\section{REFERENCES}

Awad, M., F. Hammad, A. Aly and M. Sadek (1994). Use of environmental isotopes and hydrochemistry as indicators for the origin of groundwater resources in $\mathrm{El}$ Dabaa area, northwestern coastal zone of Egypt. Envir. Geochemistry and Health, 16 (1): 31-38.

Casas, S. (1995). Salinity assessment based on combined use of remote sensing and GIS. In Use of Remote Sensing Techniques in Irrigation and Drainage Unknown, pp. 141-150, FAO, Rome, Italy.

Ceuppens, J., M. Wopereis and K. Miezan (1997). Soil salinization processes in rice irrigation schemes in the Senegal river delta. Soil Science Society of America Journal 61:1122-1130.

Douaoui, A., H. Nicolas and C. Walter (2006). Detecting salinity hazards within a semiarid context by means of combining soil and remote-sensing data. Geoderma, 134 (1-2): 217-230, 2006.

Elhag, M. (2016). Evaluation of different soil salinity mapping using remote sensing techniques in arid ecosystems, Saudi Arabia. Hindawi Publishing Corporation Journal of Sensors. 8 . http://dx.doi.org/10.1155/2016/7596175

Elhag, M. and J. Bahrawi (2014). Cloud coverage disruption for groundwater recharge improvement using remote sensing techniques in Asir region, Saudi Arabia. Life Science Journal, 11 (1): 192-200.

El-Nahal, M., R. Abd El-Aal, A. Abdel Wahid and I. Raafat (1977). Soil studies on the Nile Delta. Egypt. J. Soil Sci., 17:55-65.

FAO (1964). High dam soil survey, U. A. R. United Nations Development Program, Rome.

Farifteh, J., A. Farshad and R. George (2006). Assessing salt-affected soils using remote sensing, solute modeling, and geophysics. Geoderma, 130:191206.

Fernandez-Buces, N., C. Siebe, S. Cram and L. Palacio (2006). Mapping soil salinity using a combined spectral response index for bare soil and vegetation: A Case Study in the Former Lake Texcoco, Mexico," Journal of Arid Environments, 65 (4): 644-667.

Goossens, R., M. De Dapper, A. Gad and Th. Ghabour (1993). A model for monitoring and prediction of soil salinity 
and waterlogging in the Ismailia area (Egypt) based on remote sensing and GIS," in Proceedings of the International Symposium on Operationalization of Remote Sensing, 6: 97-107, ITC, Enschede, The Netherlands, April 1993.

Guindy, K. (1989). Hydrogeology of the coastal zone between El Ameriya and El Hammam. Ph.D thesis, Fac. Sci., Ain Shams Univ., Cairo, p 151.

Huete, V. (1988). A Soil-Adjusted Vegetation Index (SAVI). Remote Sensing of Environment, 25 (3): 295-309.

Jiang, Z., A. Huete, J. Li and J. Qi (2007). Interpretation of the modified soiladjusted vegetation index isolines in redNIR reflectance space, J. Appl. Remote Sensing. doi:10.1117/1.2709702 (online).

Jiapaer, G., X. Chen and A. Bao (2011). A comparison of methods for estimating fractional vegetation cover in arid regions. Agricultural and Forest Meteorology, 151(12): 1698-1710.

Katawatin, R. and W. Kotrapat (2005). Use of LANDSAT-7 ETM+ with ancillary data for soil salinity mapping in northeast Thailand, Third International Conference on Experimental Mechanics and Third Conference of the Asian 2004, Sevilla, pp 708-716.

Lei, L., T. Tiyip, L. Ding, H. Jiang and A. Kelimu (2014). Study on the soil salinization monitoring based on measuredhyper spectral and HSI data. Spectroscopy and Spectral Analysis, 34 (7): 1948-1953.

Major, D., F. Baret and G. Guyot (1990). A ratio vegetation index adjusted for soil brightness. International J. of RS. 11 (5): 727-740. http://dx.doi.org.

Metternicht, G. and A. Zinck (2003). Remote sensing of soil salinity: Potentials and constraints. Remote Sensing of Environment 85:1-20.

Metternicht, G. and A. Zinck (2008). Remote sensing of soil salinization: Impact on Land Management," CRC Press.
Montandon, L. and E. Small (2008). The impact of soil reflectance on the quantification of the green vegetation fraction from NDVI. Remote Sensing of Environment, 112(4): 1835-1845.

Mougenot, B., G. Epema and M. Pouget (1993). Remote sensing of salt affected soils. Remote Sensing Reviews 7: 241259.

Narmada, K., K. Gobinath and G. Bhaskaran (2015). Monitoring and evaluation of soil salinity in terms of spectral response using geo-informatics in Cuddalore environs. International Journal of Geomatics and Geosciences 5 (4): 535 538.

Odeh, I., A. McBratney and D. Chittleborough (1995). Further results on prediction of soil properties from terrain attributes: heterotrophic kriging and regression-kriging. Geoderma, (4): 215226.

Qi, J., A. Chehbouni, A. Huete and Y. Kerr (1994a). Modified Soil Adjusted Vegetation Index (MSAVI), Remote Sensing Environ., 48: 119-126.

Qi, J., Y. Kerr and A. Chehbouni (1994b). External factor consideration in vegetation index development, Proceedings of Physical Measurements and Signatures in Remote Sensing, ISPRS, pp.723-730.

Rao, B., R. Dwivedi and L. Venkataratnam (1991). Mapping the magnitude of sodicity in part of the Indo-Gangetic plains of Uttar Pradesh, northern India using Landsat-TM data. International Journal of Remote Sensing, 12 (3): 419425.

Ray, T. (2011). A FAQ on vegetation in remote sensing. URL: http://www.yale.edu/ceol Documentation/rsvegfaq.html.

Rouse, J., R. Haas, J. Schell and D. Deering (1973). Monitoring vegetation systems in the Great Plains with ERTS, Third ERTS Symposium, NASA SP-351 (I): 309-317. 
Rumiana, K., G. Georgi and B. Denitsa (2015). Optical remote sensing of saltaffected soils. 7th BgGS National Conference With International Participation "GEOPHYSICS 2015"

Sadia, I. and M. Nikos (2005). Soil salinity mapping and monitoring using remote sensing GIS. Advances in Environmental and Agricultural Science. ISBN: 978-161804-270-5.

Shaaban, F. (2001). Vertical electrical soundings for groundwater investigation in northwestern Egypt: a case study in a coastal area. Journal of African Earth Sciences, 33(3-4): 673-686.

Sharaky, A., S. Atta, A. El Hassanein and K. Khallaf (2007). Hydro geochemistry of Groundwater in the Western Nile Delta Aquifers, Egypt, $2^{\text {nd }}$ International Conference on the Geology of Tethys, Cairo University.

Shata, A., M. El- Shazly, S. Attia and Aboul M. Fetouh (1978). The geology of quaternary deposits and their mutual relation to soil formation in the Fringes West of the Nile Delta, Egypt. Desert Inst. Bull., A.R.E., 28 (1): 43-77.

Sheng, M., M. Tang, H. Chen, B. Yang, F. Zhang and Y. Huang (2008). Influence of arbuscularmycorrhizae on photosynthesis and water status of maize plants under salt stress, Mycorrhiza, 18 (6-7): 287-296.
UNEP, (2007). Annual report: Message from the UN secretary- general. United Nation Environment Program.

Wardlow, B. and S. Egbert (2008). Largearea crop mapping using time series MODIS 250m NDVI data: an assessment for the US Central Great Plains. Remote Sensing of Environment, 112 (3): 10961116.

Wesis, J., D. Gutlzer, A. Coonrod and N. Dahm (2004). Long term Vegetation Monitoring with NDVI in a Diverse Semiarid Setting, Central New Mexico, USA. J. of Arid Environments, 58:248-271.

Yang, Z., J. Gao and C. Zhou (2011). Spatio-temporalchanges of NDVI and its relation with climatic variables inthe source regions of the Yangtze and Yellow rivers," Journal of Geographical Sciences, 21 (6): 979-993.

Zhang, C., J. Tang, X. Yu, C. Wang and S. Mi (2013). Quantitative retrieval of soil salt content based on remote sensing in the Yellow River delta. Journal of Graduate University of Chinese Academy of Sciences, (30): 220-227.

Zhang, T., G. Zhao and C. Chang (2015). Information extraction method of soil salinity in typical areas of the yellow river delta based on Landsat imagery," Agricultural Sciences, 6 (1): 71-77. 
التقدم في رصد ملوحة التربة في المناطق الجافة وشبه الجافة باستخدام

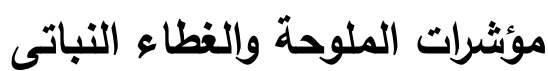

عادل سعد الحسنين (1)، سامي عبد الجيد عبدالهُ(2)، نجلاء صالح محمد (1)

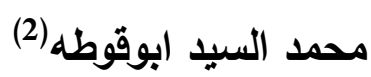

$$
\begin{aligned}
& \text { (1) معهد البحوث والدراسات الافريقية- جامعة القاهرة- مصر }
\end{aligned}
$$

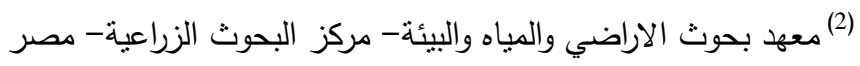

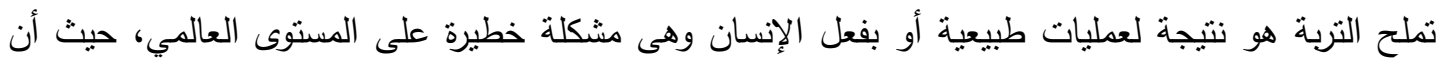

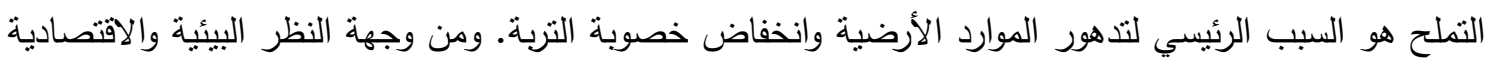

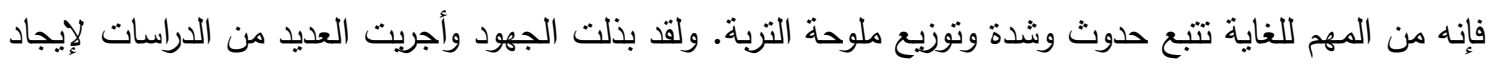

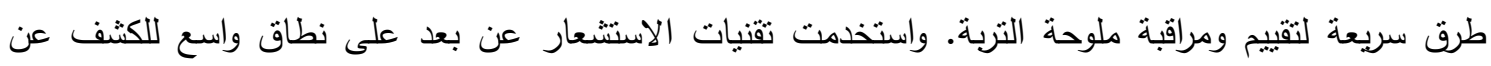
وإعداد خرائط المناطق المتأثرة بتملح التربة. والمؤشرات المستخدمة في هذا البحث هي تطبيع مؤشر التفاضلية الغطاء النباتي (NDVI))، مؤشر تطبيع الفرق الملوحة (NDSI) ومؤشر التربة لضبط الغطاء النباتي المعدل

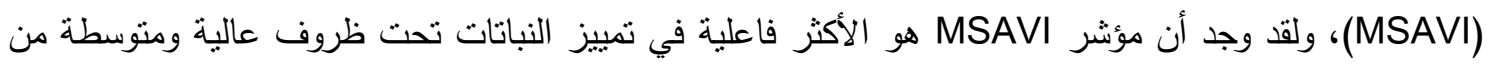
ملوحة التربة وكذلك في ظل ظروف التربة غير المالحة. وقد استخدمت تقنية تحليل الاتجاه الزمني للكثف عن

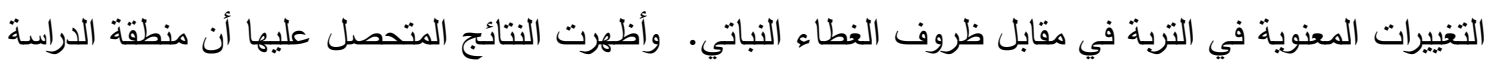
مكسوه معظمها بالمحاصيل الحقلية حيث كانت قيم NDVI تتراوح بين صفر و 0,820، و 0,70 وأيضا قيم NDSI أظهرت أراضي ذات درجات ملوحة مختلفة حيث تراوحت قيمها بين 0,01 و 0,0,89.

البريد الالكترونى

E-mail:mujareg@gmail.com
موقع المجلة

Mujareg.blogspot.com 
El-Hassanin, et al. 